\title{
Validation of the Lysine Requirement as Reference Amino Acid for Ideal In-Feed Amino Acid Ratios in Modern Fast Growing Meat-Type Chickens
}

\author{
Christian Wecke', Anja Pastor ${ }^{2}$, Frank Liebert ${ }^{1}$ \\ ${ }^{1}$ Department of Animal Sciences, Division Animal Nutrition Physiology, Georg-August-University of Goettingen, \\ Goettingen, Germany \\ ${ }^{2}$ Phytobiotics Futterzusatzstoffe GmbH, Eltville, Germany \\ Email: flieber@gwdg.de
}

Received 9 May 2016; accepted 21 June 2016; published 24 June 2016

Copyright (C) 2016 by authors and Scientific Research Publishing Inc.

This work is licensed under the Creative Commons Attribution International License (CC BY). http://creativecommons.org/licenses/by/4.0/

(c) (i) Open Access

\begin{abstract}
Nitrogen $(\mathrm{N})$ balance studies were conducted with male growing broiler chickens to reevaluate the lysine (Lys) requirement of a modern broiler strain (Ross 308), making use of eight diets with graded crude protein (CP) supply (6\% - 34\% CP as-fed). Wheat, soy protein concentrate, wheat gluten, fishmeal and crystalline amino acids (AAs) were the protein sources in the experimental diets with Lys as limiting AA. Following an adaptation period of five days, two consecutive excreta collection periods $(2 \times 5 \mathrm{~d})$ were conducted: $10-20 \mathrm{~d}$ of age (starter period) and $25-35 \mathrm{~d}$ of age (grower period). Statistical evaluation of $\mathrm{N}$ balance data utilized an exponential modelling approach. Based on different dietary Lys efficiency, Lys requirement data were derived by modelling depending on average body weight (BW) during starter and grower period and targeted body protein deposition (PD), respectively. In addition, the influence of graded feed intake was taken into account. For the starter period at $600 \mathrm{~g}$ BW and assumed $10 \mathrm{~g}$ daily body PD, Lys requirement data between $741 \mathrm{mg}$ and $823 \mathrm{mg}$ per day were observed. The corresponding Lys in-feed concentration was $1.06 \%$ and $1.18 \%$, dependent on supposed Lys efficiency at $70 \mathrm{~g}$ daily feed intake. For the grower period (average BW $1800 \mathrm{~g}$ ), $1272 \mathrm{mg}$ to $1473 \mathrm{mg}$ Lys per day was needed to yield 16.5 $\mathrm{g}$ daily $\mathrm{PD}$. The corresponding required Lys in-feed concentration was between $0.85 \%$ and $0.94 \%$ Lys for $150 \mathrm{~g}$ daily feed intake.
\end{abstract}

\section{Keywords}

Growing Chicken, Lysine Requirement, N Utilization Model, Amino Acid Efficiency 


\section{Introduction}

Currently, fast growing chickens are supposed both to achieve high yields of protein deposition and minimized nitrogen $(\mathrm{N})$ excretions per unit $\mathrm{N}$ deposition. One approach to realize these nutritional aims is the concept of dietary "Ideal Amino Acid Ratio" (IAAR) which was introduced by Cole et al. [1] and later on by the British Agricultural Research Council [2]. However, even before the 1980s nutritionists emphasized the importance of an "ideal protein" and its contribution to an effective feed conversion [3]-[5]. Currently, the IAAR concept is widely accepted in poultry nutrition as reviewed by Baker [6]. Thereby, the individual indispensable amino acids (AAs) are related to a reference AA, mostly lysine (Lys) which is almost exclusively utilized for body protein accretion [7]-[9].

Many reports evaluated the Lys requirement of modern meat-type chickens. Generally, the up to now suggested in-feed concentrations of Lys differ widely from $0.7 \%$ to $1.4 \%$ and $0.6 \%$ to $1.1 \%$ for starter and grower diets, respectively. As indicated below, such high variation of recommended dietary Lys content is observed both in terms of total and digestible Lys. Accordingly, a valid recommendation is still required. Based on earlier applications of a non-linear $\mathbf{N}$ utilization model [10]-[20] the present study aimed to reevaluate Lys requirement data of male broiler chickens dependent on age period, daily body protein deposition and real feed intake to enable further application of the modeling approach as a prediction device for promising concepts to improve traditional procedures for IAAR concepts [6]-[9] [21]-[26].

\section{Materials and Methods}

The experiments were conducted at the facilities of the Division Animal Nutrition Physiology, Department of Animal Sciences at Georg-August-University of Goettingen, Germany, and approved by the Lower Saxony Federal Office for Consumer Protection and Food Safety (LAVES).

\subsection{Housing and Management}

Day old male meat-type chicken (Ross 308) from a commercial hatchery were reared in a floor pen under standardized housing and feeding conditions up to the start of the $\mathrm{N}$ balance trials involving both starter and grower period. At day 5 and day 20 chicken (36 birds in each period) were randomly allotted to the experimental diets and individually housed in metabolic cages with wire floors $(25 \times 30 \mathrm{~cm}$ for starter and $80 \times 80 \mathrm{~cm}$ for grower period), individual feeders and a self-drinking system. The room temperature was gradually reduced from $30^{\circ} \mathrm{C}$ to $23^{\circ} \mathrm{C}$ with increasing age of the birds. Humidity was maintained between $60 \%-70 \%$ and light was provided for 23 hours per day. The study utilized only male chicken to eliminate gender effects on results of individual $\mathrm{N}$ balance measures.

\subsection{Diets and Feeding}

A computer-aided feed optimizing program (Fumi for Windows 4, HYBRIMIN ${ }^{\circledR}$ Computer + Programme GmbH \& Co. KG, Hessisch Oldendorf, Germany) was utilized for formulation of an AA balanced reference diet (Table 1) with AA pattern near to IAAR as derived from literature data [14] [15]. Based on a mixture of wheat, soy protein concentrate, wheat gluten, fishmeal and crystalline feed AAs, the postulated IAAR could be achieved for most of the indispensable AAs, except for histidine, leucine and phenylalanine.

According to principles of the applied approach, the AA under investigation is needed in a limiting position. Consequently, to ensure Lys as limiting AA (LAA) all experimental diets (Table 1) only contained native feed protein sources without L-lysine $\cdot \mathrm{HCl}$ at a total Lys level of $85 \%(5.01 \mathrm{~g} / 16 \mathrm{~g} \mathrm{~N})$ as compared to the reference diet $(5.89 \mathrm{~g} / 16 \mathrm{~g} \mathrm{~N})$. The formulated initial high protein summit diet with $38 \%$ crude protein (CP) in dry matter (DM) was subsequently stepwise diluted with wheat starch to yield eight experimental diets with graded CP contents between $38 \%$ and $6 \%$ of DM. According to these principles of diet dilution technique [29], a consistent protein quality (AA pattern) in all experimental diets was ensured (Table 2). Further details about diet composition and nutritive value were already reported by Pastor et al. [14].

During N balance experiments, birds were fed slightly restricted to minimize feed spillage and excreta contamination. Feed intake was under daily control and adapted to birds need according to Samadi and Liebert [11]. 
Table 1. Ideal amino acid ratios (IAAR) related to lysine (Lys = 100) in the experimental diets compared with literature data and targeted reference diet.

\begin{tabular}{|c|c|c|c|c|c|}
\hline & NRC [27] & GRRS [28] & Pastor et al. [14] & Reference diet $^{1}$ & Experimental diets ${ }^{2}$ \\
\hline Lysine (Lys) & 100 & 100 & 100 & 100 & $100(5.01)$ \\
\hline Methionine (Met) & 42 & 37 & 38 & 49 & $57(2.87)$ \\
\hline Methionine + Cystine (Met + Cys) & 72 & 71 & 74 & 74 & 87 (4.37) \\
\hline Threonine (Thr) & 74 & 67 & 65 & 65 & $77(3.84)$ \\
\hline Tryptophan (Trp) & 18 & 16 & 17 & 17 & $20(1.00)$ \\
\hline Arginine (Arg) & 110 & 108 & 106 & 106 & $124(6.22)$ \\
\hline Histidine (His) & 32 & 32 & 34 & 41 & $48(2.39)$ \\
\hline Isoleucine (Ile) & 73 & 69 & 68 & 69 & $81(4.04)$ \\
\hline Valine (Val) & 82 & - & 79 & 79 & $93(4.67)$ \\
\hline Leucine (Leu) & 109 & 112 & 110 & 122 & $143(7.16)$ \\
\hline Phenylalanine (Phe) & 65 & 65 & 66 & 79 & $93(4.67)$ \\
\hline Phenylalanine + Tyrosine $(\mathrm{Phe}+\mathrm{Tyr})$ & 122 & 118 & 118 & 139 & $163(8.18)$ \\
\hline
\end{tabular}

NRC: National Research Council; GRRS: German Recommendations for Requirement Standards. ${ }^{1}$ Amino acid balanced computer-aided reference diet (5.89 g lysine/16 g N) based on feed protein sources (see Table 2) including crystalline L-lysine $\cdot \mathrm{HCl}$. ${ }^{2}$ In experimental diets N1-N8 no L-lysine $\cdot \mathrm{HCl}$ was supplemented to set lysine in limiting position (in parentheses: amino acid concentrations in $\mathrm{g}$ per $16 \mathrm{~g} \mathrm{~N}$ ).

Table 2. Composition of the experimental diets ${ }^{1}$ based on a constant mixture of feed protein sources with adjusted graded dietary protein contents according to diet dilution technique.

\begin{tabular}{ccccccccc}
\hline Ingredients & Wheat & Soy protein concentrate & Wheat gluten & Fish meal & DL-Met $^{2}$ & L-Val $^{2}$ & L-Thr $^{2}$ & L-Trp $^{2}$ \\
\hline Mixture $(\%)^{3}$ & 47.48 & 40.53 & 6.86 & 4.22 & 0.59 & 0.20 & 0.12 & 0.007 \\
\hline
\end{tabular}

${ }^{1}$ Dietary crude protein contents in the experimental diets $(\mathrm{g} / \mathrm{kg} \mathrm{DM})$ : N1 = 65, N2 = 108, N3 = 152, N4 = 197, N5 = 241, N6 = 286, N7 = 332, N8 = 378 [14], ${ }^{2}$ Crystalline feed amino acids: DL-methionine, L-valine, L-threonine, L-tryptophan, ${ }^{3}$ Ratio of feed protein sources in all experimental diets (in percent as fed).

\subsection{Sample Collection}

Following a $5 \mathrm{~d}$ adaptation period, two consecutive quantitative collection periods ( $5 \mathrm{~d}$ each) were conducted from d 10 - 20 in starter and from d 25 - 35 in grower period to obtain two individual measures per bird and age period, respectively. Excreta were collected every 12 hours and stored at $-20^{\circ} \mathrm{C}$ until further analysis. Feathers and spilled feed pellets were carefully removed from excreta. Additionally, spilled feed was quantified for precise measures of daily feed intake.

\subsection{Laboratory Analysis}

Diets were ground to $1 \mathrm{~mm}$ and analyzed for N, DM, starch, sugar and fat, according to German Standards [30]. Individual AA content of the protein sources was analyzed by ion-exchange chromatography (Biochrom 30, ONKEN Ltd., Gruendau, Germany) following acid hydrolysis both with and without an oxidation step for quantitative determination of the sulphur-containing AAs.

Excreta were carefully defrosted and homogenized. Subsequently, representative samples were taken and analyzed for $\mathrm{N}$ according to the DUMAS method (TruMac ${ }^{\odot}$, LECO, Moenchengladbach, Germany) and for DM, according to German Standards [30].

\subsection{Model Application and Statistics}

Data analysis utilized current applications of an exponential N utilization model [10]-[15] [19] [20] [31]-[34] based on the fundamental work of Gebhardt [35]:

$$
\mathrm{NR}=\mathrm{NR}_{\max } \mathrm{T}\left(1-\mathrm{e}^{-b \cdot \mathrm{NI}}\right)
$$




$$
\begin{gathered}
\mathrm{ND}=\mathrm{NR}_{\text {max }} \mathrm{T}\left(1-\mathrm{e}^{-b \cdot \mathrm{NI}}\right)-\mathrm{NMR} \\
b=\left[\mathrm{In} \mathrm{NR}_{\text {max }} \mathrm{T}-\mathrm{In}\left(\mathrm{NR}_{\text {max }} \mathrm{T}-\mathrm{NR}\right)\right] / \mathrm{NI}
\end{gathered}
$$

where: $\mathrm{NR}\left(\mathrm{mg} / \mathrm{BW}_{\mathrm{kg}}{ }^{0.67}\right)$ is the daily $\mathrm{N}$ retention; $\mathrm{NR}_{\max } \mathrm{T}\left(\mathrm{mg} / \mathrm{BW}_{\mathrm{kg}}{ }^{0.67}\right)$ is the theoretical maximum for daily $\mathrm{N}$ retention; e is the basic number of natural logarithm $(\ln ) ; b$ is the slope of the $\mathrm{N}$ retention curve (indicating the feed protein quality independent on $\mathrm{N}$ intake); $\mathrm{NI}\left(\mathrm{mg} / \mathrm{BW}_{\mathrm{kg}}{ }^{0.67}\right)$ is the daily $\mathrm{N}$ intake; $\mathrm{ND}\left(\mathrm{mg} / \mathrm{BW}_{\mathrm{kg}}{ }^{0.67}\right)$ is the daily $\mathrm{N}$ deposition; and $\mathrm{NMR}\left(\mathrm{mg} / \mathrm{BW}_{\mathrm{kg}}{ }^{0.67}\right)$ is the daily $\mathrm{N}$ maintenance requirement.

Transformation of Equation (3), were $\mathrm{N}$ intake (NI) is replaced by the intake of LAA (LAAI), yields Equation (4) and allows deduction of AA requirement data for a targeted NR resp. ND according to earlier reports [10]-[12] [20] [31] [33]:

$$
\mathrm{LAAI}=\left[\mathrm{In} \mathrm{NR}_{\max } \mathrm{T}-\mathrm{In}\left(\mathrm{NR}_{\max } \mathrm{T}-\mathrm{NR}\right)\right] / 16 \cdot b c^{-1}
$$

where: LAAI (mg/BW $\left.{ }_{\mathrm{kg}}{ }^{0.67}\right)$ is the daily intake of the LAA; ln is the natural logarithm; $\mathrm{NR}_{\max } \mathrm{T}\left(\mathrm{mg} / \mathrm{BW}_{\mathrm{kg}}{ }^{0.67}\right)$ is the theoretical maximum for daily NR; $\mathrm{NR}\left(\mathrm{mg} / \mathrm{BW}_{\mathrm{kg}}{ }^{0.67}\right)$ is the daily $\mathrm{N}$ retention (ND + NMR); $b$ is the slope of the $\mathrm{N}$ retention curve (indicating the dietary protein quality independent on $\mathrm{N}$ intake); $c$ is the concentration of the LAA in the dietary protein $(\mathrm{g} / 16 \mathrm{gN}) ; b c^{-1}$ is the slope between $c$ and $b$ (model parameter, indicating the dietary AA efficiency). The multiplier 16 results from LAA concentration in the dietary protein (g/16 gN).

Earlier reports [36]-[38] also validated the linear relationship between LAA concentration (c) in the feed protein and the response on dietary protein quality (model parameter $b$ ). In consequence, the quotient $b c^{-1}$ defines the slope of the linear relationship and indicates the efficiency of the LAA in the diet [10]-[12] [14] [15] [19] [20] [33]. The term "efficiency" summarizes the AA utilization for NR in the body taking into account both digestion, absorption and post-absorptive AA utilization.

Model parameters NMR and $\mathrm{ND}_{\max } \mathrm{T}$ were basically predicted in a previous study [14]. However, according to earlier reports [11] [33] the modelling of Lys requirement data applied averaged "working values" for both NMR and $\mathrm{ND}_{\max } \mathrm{T}$ (Table 3). Accordingly, $\mathrm{N}$ balance data from Pastor et al. [14] were adapted to actual NMR and $\mathrm{ND}_{\max } \mathrm{T}$, respectively. As expected, within age periods no significant difference of dietary protein quality $(b)$ between the experimental diets was observed.

Modelling of Lys requirements considered, approximated zoo-technical data of male Ross 308 chicken (Aviagen, 2014) for mean body weight (BW: $600 \mathrm{~g}$ and $1800 \mathrm{~g}$ ), body weight gain (BWG: $60 \mathrm{~g} / \mathrm{d}$ and/100 g/d) and daily feed intake (FI: $80 \mathrm{~g} / \mathrm{d}$ and $170 \mathrm{~g} / \mathrm{d}$ ) during starter and grower period as reference criteria, respectively (Table 4).

\section{Results}

The results of modelling Lys requirement data depending on BW, age period, daily body protein deposition (PD), dietary Lys efficiency and level of feed intake (FI) are summarized in Table 4. Current objectives for zoo technical parameters of male Ross 308 broilers [39] for mean BW, BWG and FI within both of the age periods are utilized as reference criteria. Based on our database and taking into account results of Fatufe et al. [40], a CP content of $16.5 \%$ in the BWG of chicks was assumed. Accordingly, an average PD of $10 \mathrm{~g}$ and $16.5 \mathrm{~g}$ per day was assumed for starter and grower period, respectively. Furthermore, according to earlier reports [10]-[12] [20] [31] [33] the modelling of Lys requirement data applied graded dietary Lys efficiency estimates based on mean

Table 3. Summarized model parameters for daily nitrogen maintenance requirement (NMR) ${ }^{1}$ and age-depending theoretical

\begin{tabular}{|c|c|c|c|c|}
\hline Age Period & NMR & $\mathrm{ND}_{\max } \mathrm{T}$ & $b$ & $b c_{L y s}{ }^{-1}$ \\
\hline & \multicolumn{2}{|c|}{ [mg N/BW ${ }_{\mathrm{kg}}^{0.67}$ per day] } & {$\left[b \cdot 10^{6}\right]$} & {$\left[b c_{\text {Lys }}^{-1} \cdot 10^{6}\right]$} \\
\hline Starter (d 10 - 20) & 240 & 4000 & $266 \pm 29$ & $53.1 \pm 5.9$ \\
\hline Grower (d 25 - 35) & 240 & 3200 & $323 \pm 41$ & $64.5 \pm 8.3$ \\
\hline
\end{tabular}
potential for daily nitrogen deposition $\left(\mathrm{ND}_{\max } \mathrm{T}\right)^{1}$ of male meat-type Ross 308 chickens, and calculated protein quality $(b)$ and lysine efficiency $\left(b c_{L y s}{ }^{-1}\right)$ parameters of the utilized experimental diets (Mean \pm standard deviation).

\footnotetext{
${ }^{1}$ Applied as averaged "working values" from previous experiments [11] [14] [34].
} 
Table 4. Model calculation of lysine requirement for male meat-type chickens (Ross 308) during starter and grower period depending on assumed performance data, supposed different dietary Lys efficiency and predicted daily feed intake.

\begin{tabular}{|c|c|c|c|c|c|c|c|c|c|}
\hline \multicolumn{10}{|c|}{ Starter period (d 10 - 20, mean body weight $600 \mathrm{~g}$ ) } \\
\hline $\mathrm{PD}(\mathrm{g} / \mathrm{d})$ & & 9 & & & 10 & & & 11 & \\
\hline BWG (g/d) & & 55 & & & 61 & & & 67 & \\
\hline & $(1)$ & $(2)$ & (3) & $(1)$ & $(2)$ & (3) & (1) & (2) & (3) \\
\hline$b c_{L y s}{ }^{-1}$ & 53.1 & 50.4 & 47.8 & 53.1 & 50.4 & 47.8 & 53.1 & 50.4 & 47.8 \\
\hline $\begin{array}{l}\text { Lys required } \\
\left(\mathrm{mg} / \mathrm{BW}_{\mathrm{kg}}{ }^{0.67}\right)\end{array}$ & 901 & 948 & 1001 & 1044 & 1099 & 1160 & 1206 & 1270 & 1340 \\
\hline$(\mathrm{mg} / \mathrm{d})$ & 640 & 673 & 711 & 741 & 780 & 823 & 857 & 902 & 952 \\
\hline \multicolumn{10}{|c|}{ Lys concentration needed in the starter diet (\%) } \\
\hline \multicolumn{10}{|l|}{$\mathrm{FI}(\mathrm{g} / \mathrm{d})$} \\
\hline 70 & 0.91 & 0.96 & 1.02 & 1.06 & 1.12 & 1.18 & 1.22 & 1.29 & 1.36 \\
\hline 80 & 0.80 & 0.84 & 0.89 & 0.93 & 0.98 & 1.03 & 1.07 & 1.13 & 1.19 \\
\hline 90 & 0.71 & 0.75 & 0.79 & 0.82 & 0.87 & 0.92 & 0.95 & 1.00 & 1.06 \\
\hline \multicolumn{10}{|c|}{ Grower period (d 25 - 35, mean body weight $1800 \mathrm{~g}$ ) } \\
\hline $\mathrm{PD}(\mathrm{g} / \mathrm{d})$ & & 15 & & & 16.5 & & & 18 & \\
\hline BWG (g/d) & & 91 & & & 100 & & & 109 & \\
\hline & $(1)$ & (2) & (3) & (1) & (2) & (3) & (1) & (2) & (3) \\
\hline$b c_{L y s}^{-1}$ & 64.5 & 61.3 & 58.1 & 64.5 & 61.3 & 58.1 & 64.5 & 61.3 & 58.1 \\
\hline $\begin{array}{l}\text { Lys required } \\
\left(\mathrm{mg} / \mathrm{BW}_{\mathrm{kg}}^{0.67}\right)\end{array}$ & 753 & 793 & 837 & 858 & 903 & 953 & 975 & 1026 & 1083 \\
\hline$(\mathrm{mg} / \mathrm{d})$ & 1117 & 1175 & 1241 & 1272 & 1339 & 1413 & 1446 & 1522 & 1606 \\
\hline \multicolumn{10}{|c|}{ Lys concentration needed in the grower diet (\%) } \\
\hline \multicolumn{10}{|l|}{ FI (g/d) } \\
\hline 150 & 0.74 & 0.78 & 0.83 & 0.85 & 0.89 & 0.94 & 0.96 & 1.02 & 1.07 \\
\hline 170 & 0.66 & 0.69 & 0.73 & 0.75 & 0.79 & 0.83 & 0.85 & 0.90 & 0.95 \\
\hline 190 & 0.59 & 0.62 & 0.65 & 0.67 & 0.70 & 0.74 & 0.76 & 0.80 & 0.84 \\
\hline
\end{tabular}

$\mathrm{PD}=$ average daily protein deposition ( $\mathrm{N}$ deposition-6.25), BWG = average daily body weight gain (crude protein in BWG: $16.5 \%), b c_{L y s}{ }^{-1}=\mathrm{Lys}_{\mathrm{S}}$ efficiency [(1) as observed, (2) 5\% lower as observed, (3) 10\% lower as observed], Lys required = lysine requirement for targeted PD, FI = average daily feed intake.

age-dependent dietary Lys efficiency data as shown in Table 3. Due to the current ingredient composition (Table 2), according to Evonik tables [41] a high level of standardized ileal digestible Lys (88\%) was expected. Additionally, relating to the aimed level of dietary AA balance (Table 1), the observed dietary Lys efficiency (1) was stated in the upper level of practical diets for growing chicken. Consequently, in Table 4 a graded decline of Lys efficiency by 5 percent (2) and 10 percent (3) was utilized to rank the yielded data more in line with expectations for practical feeds. Finally, graded expectations for daily feed intake according to Aviagen [39] were applied for predictions of needed in-feed concentration of Lys.

Generally, the metabolic BW-related Lys requirement $\left(\mathrm{mg} / \mathrm{BW}_{\mathrm{kg}}{ }^{0.67} / \mathrm{d}\right)$ declined with increasing BW and age, while the absolute daily Lys requirement (mg/d) increased. The needed in-feed Lys concentration also declined with advancing age. Accordingly, higher Lys supply is required both for birds with elevated daily PD and lower level of dietary Lys efficiency. However, lower FI levels reveal higher Lys concentrations to achieve optimal performance data.

Male starter chickens of $600 \mathrm{~g}$ BW require 750 to $950 \mathrm{mg}$ Lys depending on the assumed Lys efficiency to yield 10 to $11 \mathrm{~g}$ daily PD (about 60 to $70 \mathrm{~g} / \mathrm{d}$ BWG). At individual FI level between 70 and $80 \mathrm{~g}$ per day, 0.9\% to $1.4 \%$ Lys in the starter feed is needed to achieve this PD with varying Lys efficiency. Male grower chicken of $1800 \mathrm{~g}$ BW and 100 to $110 \mathrm{~g} / \mathrm{d}$ BWG (16.5 - $18 \mathrm{~g} / \mathrm{d} \mathrm{PD})$ need $1.3 \mathrm{~g}$ to $1.6 \mathrm{~g}$ Lys per day corresponding to $0.7 \%$ 
and $1.1 \%$ Lys in the diet when the variation of both FI and dietary Lys efficiency is taken into account.

\section{Discussion}

The observed variation of Lys requirement data yielded by applied modelling procedure is in line with variation of current recommendations. Growth response of growing meat type chickens depending on dietary Lys supply was in focus of numerous studies. Recommendations of NRC [27] based on a review of 20 references summarized 1.1\% total Lys for birds between 0 and 3 weeks and 1.0\% total Lys for birds between 3 and 6 weeks of age. However, the analyzed individual studies published between 1942 and 1981 ranged from $0.70 \%$ to $1.18 \%$ Lys and from $0.59 \%$ to $1.05 \%$ Lys in diets for the starter and grower period, respectively. Vazques and Pesti [42] evaluated 16 data sets from 7 reported studies and concluded 1.21\% and 1.32\% Lys in starter diets for the response criteria BWG and feed efficiency, respectively. The GRRS [28] reviewed more than 40 original papers and concluded optimal Lys contents in the DM of broiler diets between $1.3 \%$ and $1.1 \%$ during the first 5 weeks of age. Relandeau and Le Bellego [43] reported a total of 25 publications and results of 20 dose-response studies demonstrating that elevated Lys recommendations are needed for modern genotypes. Similar conclusions were reported by Aftab [44] following data analyses from 65 dose-response studies published from 1993 to 2010, involving Lys limiting diets with widely different ingredient composition. For maximum BWG and feed efficiency, an optimal digestible Lys content of $1.13 \%$ to $1.17 \%$ ( 1 to $21 \mathrm{~d}$ ) and $1.04 \%$ to $1.08 \%$ (22 to 42 d) was recommended in starter and grower diets, respectively.

Generally, direct comparisons between results of modelling and earlier requirement estimates are questionable according to the direct dependencies on modulated PD, Lys efficiency and FI data. It is well documented that derived AA requirements of growing chickens depend on many animal and environmental factors [12] [44]-[51]. Genotype, gender, age period, BW and expected growth performance of birds have to be considered for valid recommendations. The fast breeding progress in meat-type chicken [52] [53] has an impact on derived Lys requirement data too. Modern broiler genotypes require significantly higher dietary Lys concentrations to optimize performance and body composition as compared to broilers of past years [54]-[59]. In addition, diet composition regarding the feed ingredients, dietary protein concentration, AA balance, AA availability and the presence of anti-nutritional factors may also act as factors of influence.

Furthermore, the applied experimental approach (dose-response studies, diet dilution technique, factorial methods, metabolic based procedures) and particularly the selected response criteria (BWG, feed efficiency, PD, carcass yields, physiological parameters) are additional factors of influence. Earlier reports showed that more Lys is necessary for maximum PD and carcass yields as compared to the supply needed for optimal feed efficiency and BWG [21] [48] [51] [55] [60]-[62]. Finally, the applied statistical model for assessing AA requirements (broken-line models, non-linear regression analyses, response surface methods, etc.) considerably impacts on validity of concluded Lys requirement data [9] [42] [48] [54]-[57] [63]-[66]. Our modelling approach involves both BW and graded performance data (PD, BWG). Additionally are considered, variation of dietary Lys efficiency and predicted FI data, respectively. Taking into account these important factors of influence, remarkable modulations of the derived optimal Lys concentration in the diet of modern meat-type chickens is not surprising (Table 4).

Even if requirement data are expressed in terms of total or digestible Lys, regardless of apparent, standardized or true ileal digestible Lys, the observed considerable variation of requirement data did not decline. Throughout the past 12 years, requirement estimates between $0.98 \%$ and $1.41 \%$ total Lys [67]-[71] vs. $0.93 \%$ and $1.38 \%$ digestible Lys [41] [51] [55] [58] [66] [69] [72]-[74] in starter diets and between $0.91 \%$ and $1.13 \%$ total Lys [57] [70] vs. 0.84\% and 1.05\% digestible Lys [41] [51] [55] [75]-[77] in grower diets of meat-type chickens were reported. Finally, a further explanation for the observed high variation is that the concluded requirements are only in part directly related to body PD. Assessing the ileal Lys digestibility meets only a part of losses during the total utilization process. Losses of Lys taking place during post-absorptive utilization processes [78] [79], as taken into account by the dietary AA efficiency approach [20], need more attention as an additional factor of influence on derived AA requirement data in the future.

\section{Conclusions}

The presented modelling of Lys requirements based on data evaluation by "Goettingen approach" demonstrates that an adequate dietary Lys supply to yield optimal performance data and feed efficiency in broiler chicken 
production is influenced by different animal factors, especially the age period, the assumed growth (PD) performance and the realized FI. In addition, dietary factors influencing the Lys efficiency have to be taken into account. The observed high variation of recommendations to meet the Lys needs in meat type chicken requires more investigations, but also more standardized experimental conditions for more validated conclusions.

Generally, a fine structured network of recommendations could be achieved by modelling of requirement data which are useful for integration into feeding systems by continuous adaptation to varying BW, PD and FI, respectively. However, more reliable data are needed due to the expected variation of AA efficiency in feed ingredients. By this way, application of physiologically based new procedures like "Goettingen approach" might contribute to more validated recommendations in the future and to reducing the observed variation in conclusion of Lys requirement data.

\section{References}

[1] Cole, D.J.A., Yen, H.T. and Lewis, D. (1980) The Lysine Requirements of Growing and Finishing Pigs-The Concept of an Ideal Protein. In: Oslage, H.J. and Rohr, K., Eds., Proceedings of the $3^{\text {rd }}$ International Symposium on Protein Metabolism and Nutrition, Vol. II, EAAP, Braunschweig, Germany, 658-668.

[2] ARC (Agricultural Research Council) (1981) The Nutrient Requirement of Pigs. Commonwealth Agricultural Bureaux, Slough, UK.

[3] Almquist, H.J. and Grau, C.R. (1944) The Amino Acid Requirement of the Chick. The Journal of Nutrition, 28, 325331.

[4] Oser, B.L. (1951) Method of Integrating Essential Amino Acid Content in the Nutritional Evaluation of Protein. Journal of the American Dietetic Association, 27, 396-402.

[5] Dean, W.F. and Scott, H.M. (1965) The Development of an Amino Acid Reference Diet for the Early Growth of Chicks. Poultry Science, 44, 803-808. http://dx.doi.org/10.3382/ps.0440803

[6] Baker, D.H. (2003) Ideal Amino Acid Patterns for Broiler Chicks. In: D’Mello, J.P.F., Ed., Amino Acids in Animal Nutrition, 2nd Edition, CAB International, Wallingford, Oxon, UK, 223-235. http://dx.doi.org/10.1079/9780851996547.0223

[7] Baker, D.H. and Han, Y. (1994) Ideal Amino Acid Profile for Chicks during the First Three Weeks Posthatching. Poultry Science, 73, 1441-1447. http://dx.doi.org/10.3382/ps.0731441

[8] Emmert, J.L. and Baker, D.H. (1997) Use of the Ideal Protein Concept for Precision Formulation of Amino Acid Levels in Broiler Diets. The Journal of Applied Poultry Research, 6, 462-470. http://dx.doi.org/10.1093/japr/6.4.462

[9] Baker, D.H, Batal, A.B., Parr, T.M., Augspurger, N.R. and Parsons, C.M. (2002) Ideal Ratio (Relative to Lysine) of Tryptophan, Threonine, Isoleucine, and Valine for Chicks during the Second and Third Week Posthatch. Poultry Science, 81, 485-494. http://dx.doi.org/10.1093/ps/81.4.485

[10] Samadi and Liebert, F. (2007) Lysine Requirement of Fast Growing Chickens-Effect of Age, Sex, Level of Protein Deposition and Dietary Lysine Efficiency. The Journal of Poultry Science, 44, 63-72. http://dx.doi.org/10.2141/jpsa.44.63

[11] Samadi and Liebert, F. (2008) Modelling the Optimal Lysine to Threonine Ratio in Growing Chickens Depending on Age and Efficiency of Dietary Amino Acid Utilisation. British Poultry Science, 49, 45-54. http://dx.doi.org/10.1080/00071660701821667

[12] Liebert, F. (2008) Modelling of Protein Metabolism Yields Amino Acid Requirements Dependent on Dietary Amino Acid Efficiency, Growth Response, Genotype and Age of Growing Chicken. Avian Biology Research, 1, 101-110. http://dx.doi.org/10.3184/175815508X388074

[13] Liebert, F. and Wecke, C. (2008) Models for Further Developing the Evaluation of Protein and Amino Acids as Well as for Predicting Performance from Energy and Amino Acids Intake. In: Staudacher, W., Ed., Recommendations for the Supply of Energy and Nutrients to Pigs, DLG-Verlag-GmbH, Frankfurt, Germany, 219-230.

[14] Pastor, A., Wecke, C. and Liebert, F. (2013) Assessing the Age Dependent Optimal Dietary Branched-Chain Amino Acid Ratio in Growing Chicken by Application of a Non-Linear Modeling Procedure. Poultry Science, 92, 3184-3195. http://dx.doi.org/10.3382/ps.2013-03340

[15] Wecke, C. and Liebert, F. (2013) Improving the Reliability of Optimal In-Feed Amino Acid Ratios Based on Individual Amino Acid Efficiency Data from N Balance Studies in Growing Chicken. Animals, 3, 558-573. http://dx.doi.org/10.3390/ani3030558

[16] Wecke, C., Pastor, A. and Liebert, F. (2013) Ideal In-Feed Amino Acid Ratios for Growing Broiler Chicken Based on Individual Amino Acid Efficiency Data Derived from N Balance Studies. 19th European Symposium on Poultry Nutrition, Potsdam, File 180, 1-4. 
[17] dos Santos, P.A., Rabello, C.B.V., Sakomura, N.K., da Silva, E.P., Dorigam, J.C.P., dos Santos, M.J.P. and LorenaRezende, I.M.B. (2014) Modelling of the Nitrogen Deposition and Dietary Lysine Requirements of Redbro Broilers. Animal Production Science, 54, 1946-1952.

[18] Dorigam, J.C.P., Sakomura, N.K., Suender, A. and Wecke, C. (2015) A Comparison of Two Approaches for Determining the Optimum Dietary Amino Acid Ratios of Fast-Growing Broilers. In: Sakomura, N.K., Gous, R., Kyriazakis, I. and Hauschild, L., Eds., Nutritional Modelling for Pigs and Poultry, CAB International, Wallingford, Oxfordshire, 283-296. http://dx.doi.org/10.1079/9781780644110.0283

[19] Khan, D.R., Wecke, C. and Liebert, F. (2015) An Elevated Dietary Cystine to Methionine Ratio Does Not Impact on Dietary Methionine Efficiency and the Derived Optimal Methionine to Lysine Ratio in Diets for Meat Type Chicken. Open Journal of Animal Sciences, 5, 457-466. http://dx.doi.org/10.4236/ojas.2015.54047

[20] Liebert, F. (2015) Basics and Applications of an Exponential Nitrogen Utilization Model (“Goettingen Approach”) for Assessing Amino Acid Requirements in Growing Pigs and Meat Type Chickens Based on Dietary Amino Acid Efficiency. In: Sakomura, N.K., Gous, R., Kyriazakis, I. and Hauschild, L., Eds., Nutritional Modelling for Pigs and Poultry, CAB International, Wallingford, Oxfordshire, 73-87.

[21] Mack, S., Bercovici, D., de Groote, G., Leclercq, B., Lippens, M., Pack, M., Schutte, J.B. and van Cauwenberghe, S. (1999) Ideal Amino Acid Profile and Dietary Lysine Specification for Broiler Chickens of 20 to 40 Days of Age. British Poultry Science, 40, 257-265. http://dx.doi.org/10.1080/00071669987683

[22] Roth, F.X., Gruber, K. and Kirchgessner, M. (2001) The Ideal Dietary Amino Acid Pattern for Broiler-Chicks of Age 7 to 28 Days. Archiv für Geflügelkunde, 65, 199-206.

[23] Lemme, A. (2003) The "Ideal Protein Concept” in Broiler Nutrition. 1. Methodological Aspects—Opportunities and Limitations. AminoNews, 4, 7-14.

[24] Dari, R.L., Penz Jr., A.M., Kessler, A.M. and Jost, H.C. (2005) Use of Digestible Amino Acids and the Concept of Ideal Protein in Feed Formulation for Broilers. The Journal of Applied Poultry Research, 14, 195-203. http://dx.doi.org/10.1093/japr/14.2.195

[25] Taherkhani, R., Shivazad, M., Zaghari, M. and Zare Shahneh, A. (2008) Comparison of Different Ideal Amino Acid Ratios in Male and Female Broiler Chickens of 21 to 42 Days of Age. The Journal of Poultry Science, 45, 15-19. http://dx.doi.org/10.2141/jpsa.45.15

[26] Vieira, S.L., Taschetto, D., Angel, C.R., Favero, A., Mascharello, N.C. and Nogueira, E.T. (2012) Performance and Carcass Characteristics of Cobb $\times$ Cobb 500 Slow-Feathering Male Broilers Fed on Dietary Programs Having Stepwise Increases in Ideal Protein Density. The Journal of Applied Poultry Research, 21, 797-805. http://dx.doi.org/10.3382/japr.2012-00523

[27] NRC (1994) Nutrient Requirements of Poultry. 9th Revised Edition, National Academy Press, Washington DC.

[28] GRRS [German Recommendations for Requirement Standards (Ausschuss für Bedarfsnormen der Gesellschaft für Ernährungsphysiologie)] (1999) Empfehlungen zur Energie- und Nährstoffversorgung der Legehennen und Masthühner (Broiler). 7. DLG-Verlag, Frankfurt am Main, Germany.

[29] Gous, R.M. and Morris, T.R. (1985) Evaluation of a Diet Dilution Technique for Measuring the Response of Broiler Chickens to Increasing Concentrations of Lysine. British Poultry Science, 26, 147-161. http://dx.doi.org/10.1080/00071668508416799

[30] Naumann, C. and Bassler, R. (1997) Die chemischen Untersuchungen von Futtermitteln. Volume III, Methodenbuch, VDLUFA-Verlag, Darmstadt, Germany.

[31] Wecke, C. and Liebert, F. (2009) Lysine Requirement Studies in Modern Genotype Barrows Dependent on Age, Protein Deposition and Dietary Lysine Efficiency. Journal of Animal Physiology and Animal Nutrition, 93, 295-304. http://dx.doi.org/10.1111/j.1439-0396.2009.00923.x

[32] Wecke, C. and Liebert, F. (2010) Optimal Dietary Lysine to Threonine Ratio in Pigs (30 - 110 kg BW) Derived from Observed Dietary Amino Acid Efficiency. Journal of Animal Physiology and Animal Nutrition, 94, e277-e285. http://dx.doi.org/10.1111/j.1439-0396.2009.00969.x

[33] Khan D.R., Wecke, C. and Liebert, F. (2015) Does the Naked Neck Meat Type Chicken Yield Lower Methionine Requirement Data? Animals, 5, 151-160. http://dx.doi.org/10.3390/ani5020151

[34] Khan D.R., Wecke, C., Sharifi, A.R. and Liebert, F. (2015) Evaluating the Age-Dependent Potential for Protein Deposition in Naked Neck Meat Type Chicken. Animals, 5, 56-70. http://dx.doi.org/10.3390/ani5010056

[35] Gebhardt, G. (1966) Die Bewertung der Eiweißqualität von Nahrungs- und Futtermitteln mit Hilfe des N-Bilanzversuches. In: Hock, A., Ed., Vergleichende Ernährungslehre des Menschen und seiner Haustiere, Gustav Fischer Verlag, Jena, Germany, 323-348.

[36] Gebhardt, G. (1980) Protein and Amino Acid Utilization in Relation to Metabolism of the Limitig Amino Acid. Archiv für Tierernaehrung, 30, 63-71. (In German) http://dx.doi.org/10.1080/17450398009441181 
[37] Liebert, F. and Gebhardt, G. (1980) Relations between Lysine Concentration and Data of Protein and Amino Acid Utilization in Broiler Chickens. Archiv für Tierernaehrung, 30, 469-478. (In German) http://dx.doi.org/10.1080/17450398009430894

[38] Wecke, C. and Gebhardt, G. (1982) Investigations of the Protein Utilization of Barley Protein Supplemented by Lysine and the Effectiveness of the Limiting Amino Acid Lysine in Growing Pigs. Archiv für Tierernaehrung, 32, 221-228. (In German) http://dx.doi.org/10.1080/17450398209426895

[39] Aviagen (2014) Ross 308 Broiler: Performance Objectives. http://www.winmixsoft.com/files/info/Ross-308-Broiler-PO-2014-EN.pdf

[40] Fatufe, A.A., Timmler, R. and Rodehutscord, M. (2004) Response to Lysine Intake in Composition of Body Weight Gain and Efficiency of Lysine Utilization of Growing Male Chickens from Two Genotypes. Poultry Science, 83, 13141324. http://dx.doi.org/10.1093/ps/83.8.1314

[41] Evonik (2016) AMINODat ${ }^{\circledR}$ 5.0 - Gold. Evonik Nutrition \& Care GmbH, Animal Nutrition, Hanau, Germany. http://www.aminoacidsandmore.com

[42] Vazquez, M. and Pesti, G.M. (1997) Estimation of the Lysine Requirement of Broiler Chicks for Maximum Body Gain and Feed Efficiency. The Journal of Applied Poultry Research, 6, 241-246. http://dx.doi.org/10.1093/japr/6.3.241

[43] Relandeau, C. and Le Bellego, L. (2004) Amino Acid Nutrition of the Broiler Chicken. Update on Lysine, Threonine and Other Amino Acids. Ajinomoto Eurolysine Information, No. 27, Ajinomoto Animal Nutrition, Paris, 3-11.

[44] Aftab, U. (2012) Dietary Amino Acid Optima: An Economical Appraisal. The Journal of Applied Poultry Research, 21, 738-743. http://dx.doi.org/10.3382/japr.2011-00413

[45] Baker, D.H. (1986) Problems and Pitfalls in Animal Experiments Designed to Establish Dietary Requirements for Essential Nutrients. The Journal of Nutrition, 116, 2339-2349.

[46] Han, Y. and Baker, D.H. (1993) Effect of Sex, Heat Stress, Body Weight, and Genetic Strain on the Dietary Lysine Requirement of Broiler Chickens. Poultry Science, 72, 701-708. http://dx.doi.org/10.3382/ps.0720701

[47] Gous, R.M. (1998) Making Progress in the Nutrition of Broilers. Poultry Science, 77, 111-117. http://dx.doi.org/10.1093/ps/77.1.111

[48] Leclercq, B. (1998) Specific Effects of Lysine on Broiler Production: Comparison with Threonine and Valine. Poultry Science, 77, 118-123. http://dx.doi.org/10.1093/ps/77.1.118

[49] D’Mello, J.P.F. (2003) Responses of Growing Poultry to Amino Acids. In: D’Mello, J.P.F., Ed., Amino Acids in Animal Nutrition, 2nd Edition, CAB International, Wallingford, Oxon, 237-263. http://dx.doi.org/10.1079/9780851996547.0237

[50] Moughan, P.J. and Fuller, M.F. (2003) Modelling Amino Acid Metabolism and the Estimation of Amino Acid Requirements. In: D’Mello, J.P.F., Ed., Amino Acids in Animal Nutrition, 2nd Edition, CAB International, Wallingford, Oxon, 187-202. http://dx.doi.org/10.1079/9780851996547.0187

[51] Garcia, A.R., Batal, A.B. and Baker, D.H. (2006) Variations in the Digestible Lysine Requirement of Broiler Chickens Due to Sex, Performance Parameters, Rearing Environment, and Processing Yield Characteristics. Poultry Science, 85, 498-504. http://dx.doi.org/10.1093/ps/85.3.498

[52] Havenstein, G.B., Feket, P.R. and Qureshi, M.A. (2003) Growth, Livability, and Feed Conversion of 1957 versus 2001 Broilers When Fed Representative 1957 and 2001 Broiler Diet. Poultry Science, 82, 1500-1508. http://dx.doi.org/10.1093/ps/82.10.1500

[53] Schmidt, C.J., Persia, M.E., Feierstein, E., Kingham, B. and Saylor, W.W. (2009) Comparison of a Modern Broiler Line and a Heritage Line Unselected Since the 1950s. Poultry Science, 88, 2610-2619. http://dx.doi.org/10.3382/ps.2009-00055

[54] Dozier III, W.A., Corzo, A., Kidd, M.T., Tillman, P.B. and Branton, S.L. (2009) Digestible Lysine Requirements of Male and Female Broilers from Fourteen to Twenty-Eight Days of Age. Poultry Science, 88, 1676-1682. http://dx.doi.org/10.3382/ps.2008-00539

[55] Abudabos, A. and Aljumaah, R. (2010) Evaluation of Digestible Lysine Needs for Male Broiler. International Journal of Poultry Science, 9, 1146-1151. http://dx.doi.org/10.3923/ijps.2010.1146.1151

[56] de Coca-Sinova, A., Jimenez-Moreno, E., Gonzales-Alvarado, J.M., Frikha, M., Lazaro, R. and Mateos, G.G. (2010) Influence of Source of Soybean Meal and Lysine Content of the Diet on Performance and Total Tract Apparent Retention of Nutrients in Broilers from 1 to 36 Days of Age. Poultry Science, 89, 1440-1450. http://dx.doi.org/10.3382/ps.2010-00648

[57] Ghahri, H., Gaykani, R. and Toloie, T. (2010) Effect of Dietary Crude Protein Level on Performance and Lysine Requirements of Male Broiler Chickens. African Journal of Agricultural Research, 5, 1228-1234.

[58] Dozier III, W.A. and Payne, R.L. (2012) Digestible Lysine Requirements of Female Broilers from 1 to 15 Days of Age. 
The Journal of Applied Poultry Research, 21, 348-357. http://dx.doi.org/10.3382/japr.2011-00418

[59] Nasr, J. and Kheiri, F. (2012) Effects of Lysine Levels of Diets Formulated Based on Total or Digestible Amino Acids on Broiler Carcass Composition. Brazilian Journal of Poultry Science, 14, 249-257.

[60] Grisoni, M.L., Uzu, G., Larbier, M. and Geraert, P.A. (1991) Effect of Dietary Lysine Level on Lipogenesis in Broilers, Reproduction Nutrition Development, 31, 683-690. http://dx.doi.org/10.1051/rnd:19910608

[61] Labadan Jr., M.C., Hsu, K.-N. and Austic, R.E. (2001) Lysine and Arginine Requirements of Broiler Chickens at Twoto Three-Week Intervals to Eight Weeks of Age. Poultry Science, 80, 599-606. http://dx.doi.org/10.1093/ps/80.5.599

[62] Borges, A.F., de Oliveira, R.F.M., Donzele, J.L., Albino, L.F.T., Orlando, U.A.D. and Ferreira, R.A. (2002) Requirements of Lysine for Male Broiler Chicks under High Temperature Environment. Revista Brasileira de Zootecnia, 31, 394-401. http://dx.doi.org/10.1590/S1516-35982002000200014

[63] Barbour, G., Latshaw, J.D. and Bishop, B. (1993) Lysine Requirement of Broiler Chickens as Affected by Protein Source and Method of Statistical Evaluation. British Poultry Science, 34, 747-756. http://dx.doi.org/10.1080/00071669308417633

[64] Latshaw, J.D. (1993) Dietary Lysine Concentrations from Deficient to Excessive and the Effects on Broiler Chicks. British Poultry Science, 34, 951-958. http://dx.doi.org/10.1080/00071669308417655

[65] Coon, C. (2004) The Ideal Amino Acid Requirements and Profile for Broilers, Layers, and Broiler Breeders. Technical Information of American Soybean Association, 153, 1-43.

[66] Mehri, M. (2014) Optimization of Response Surface and Neural Network Models in Conjugation with Desirability Function for Estimation of Nutritional Needs of Methionine, Lysine, and Threonine in Broiler Chickens. Poultry Science, 93, 1862-1867. http://dx.doi.org/10.3382/ps.2013-03689

[67] Kidd, M.T., McDaniel, C.D., Branton, S.L., Miller, E.R., Boren, B.B. and Fancher, B.I. (2004) Increasing Amino Acid Density Improves Live Performance and Carcass Yields of Commercial Broilers. The Journal of Applied Poultry Research, 13, 593-604. http://dx.doi.org/10.1093/japr/13.4.593

[68] Urdaneta-Rincon, M. and Leeson, S. (2004) Muscle (Pectoralis Major) Protein Turnover in Young Broiler Chickens Fed Graded Levels of Lysine and Crude Protein. Poultry Science, 83, 1897-1903. http://dx.doi.org/10.1093/ps/83.11.1897

[69] Corzo, A., Kidd, M.T., Koter, M.D. and Burgess, S.C. (2005) Assessment of Dietary Amino Acid Scarcity on Growth and Blood Plasma Proteome Status of Broiler Chickens. Poultry Science, 84, 419-425. http://dx.doi.org/10.1093/ps/84.3.419

[70] Sklan, D. and Noy, Y. (2005) Direct Determination of Optimal Amino Acid Intake for Maintenance and Growth in Broilers. Poultry Science, 84, 412-418. http://dx.doi.org/10.1093/ps/84.3.412

[71] Panda, A.K., Rao, S.V.R., Raju, M.V.L.N., Lavanya, G., Reddy, E.P.K. and Sunder, G.S. (2011) Early Growth Response of Broilers to Dietary Lysine at Fixed Ratio to Crude Protein and Essential Amino Acids. Asian-Australasian Journal of Animal Sciences, 24, 1623-1628. http://dx.doi.org/10.5713/ajas.2011.11080

[72] Garcia, A. and Batal, A.B. (2005) Changes in the Digestible Lysine and Sulfur Amino Acid Needs of Broiler Chicks during the First Three Weeks Posthatching. Poultry Science, 84, 1350-1355. http://dx.doi.org/10.1093/ps/84.9.1350

[73] Plumstead, P.W., Romero-Sanchez, H., Paton, N.D., Spears, J.W. and Brake, J. (2007) Effects of Dietary Metabolizable Energy and Protein on Early Growth Responses of Broilers to Dietary Lysine. Poultry Science, 86, 2639-2648. http://dx.doi.org/10.3382/ps.2007-00168

[74] Mehri, M., Bagherzadeh-Kasmani, F. and Rokouei, M. (2016) Growth Responses of Breast and Leg Muscles to Essential Amino Acids in Broiler Chicks. Animal, 10, 390-395. http://dx.doi.org/10.1017/S1751731115002128

[75] Greenwood, M.W., Cramer, K.R., Beyer, R.S., Clark, P.M. and Behnke, K.C. (2005) Influence of Feed Form on Estimated Digestible Lysine Needs of Male Broilers from Sixteen to Thirty Days of Age. The Journal of Applied Poultry Research, 14, 130-135. http://dx.doi.org/10.1093/japr/14.1.130

[76] Berry, C., Besnard, J. and Relandeau, C. (2008) Increasing Dietary Lysine Increases Final pH and Decreases Drip Loss of Broiler Breast Meat. Poultry Science, 87, 480-484. http://dx.doi.org/10.3382/ps.2007-00226

[77] Dozier III, W.A., Corzo, A., Kidd, M.T., Tillman, P.B., McMurtry, J.P. and Branton, S.L. (2010) Digestible Lysine Requirements of Male Broilers from 28 to 42 Days of Age. Poultry Science, 89, 2173-2182. http://dx.doi.org/10.3382/ps.2010-00710

[78] Wu, G. (1998) Intestinal Mucosal Amino Acid Catabolism. The Journal of Nutrition, 128, 1249-1252.

[79] Stoll, B. and Burrin, D.G. (2006) Measuring Splanchnic Amino Acid Metabolism in Vivo Using Stable Isotopic Tracers. Journal of Animal Science, 84, E60-E72. 


\section{Submit or recommend next manuscript to SCIRP and we will provide best service for you:}

Accepting pre-submission inquiries through Email, Facebook, Linkedin, Twitter, etc A wide selection of journals (inclusive of 9 subjects, more than 200 journals)

Providing a 24-hour high-quality service

User-friendly online submission system

Fair and swift peer-review system

Efficient typesetting and proofreading procedure

Display of the result of downloads and visits, as well as the number of cited articles

Maximum dissemination of your research work

Submit your manuscript at: http://papersubmission.scirp.org/ 